\section{Kidney \\ Blood Pressure Research}

\title{
Effect of Intervention in Mast Cell Function Before Reperfusion on Renal Ischemia-Reperfusion Injury in Rats
}

\author{
Fei Tong Lei Luo Daojun Liu \\ Department of Chemistry, Medical College, Shantou University, Shantou, China
}

\section{Key Words}

Mast cell $\bullet$ Renal ischemia-reperfusioninjury $\bullet$ Ketotifen $•$ Cromolyn sodium

\begin{abstract}
Background/Aims: Mast cells are sparsely distributed in the kidneys under normal conditions; however, the number of mast cells increases dramatically during renal ischemia/reperfusion injury (RI/RI). When mast cells are stimulated, numerous mediators are released, and under pathological conditions, they produce a wide range of biological effects. The aim of this study was to investigate the effect of intervention in mast cell function before reperfusion on RI/RI. Methods: Sprague-Dawley (SD) rats $(n=50)$ were randomized into five groups: sham group, ischemia/reperfusion (I/R) group, cromolyn sodium treatment group (CS+I/R group), ketotifen treatment group ( $\mathrm{K}+\mathrm{I} /$ Rgroup), and compound $48 / 80$ treatment group ( $\mathrm{C}+\mathrm{I} / \mathrm{R}$ group). I/R injury was induced by bilateral renal artery and vein occlusion for $45 \mathrm{~min}$ followed by $24 \mathrm{~h}$ of reperfusion. The agents were intravenously administered $5 \mathrm{~min}$ before reperfusion through the tail vein. The serum levels of blood urea nitrogen $(\mathrm{BUN})$, serum creatinine $(\mathrm{Scr})$ and histamine and the kidney levels of malondialdehyde (MDA), superoxide dismutase (SOD), tumor necrosis factor $\alpha$ (TNF- $\alpha$ ) and interleukin- 6 (IL-6) were assessed. The expression of intracellular adhesion molecule-1 (ICAM-1) in renal tissue was also measured. Results: I/R injury resulted in severe renal injury, as demonstrated by a large increase in injury scores; serum levels of BUN, Scr and histamine; and kidney levels of MDA, TNF- $\alpha$, and IL- 6 ; this was accompanied by reduced SOD activity and upregulated ICAM-1 expression. Treatment with cromolyn sodium or ketotifen markedly alleviated I/R-mediated kidney injury, whereas compound 48/80 further aggravated kidney injury. Conclusion: Intervention in mast cell activity prior to reperfusionhas a strong effect on RI/RI.
\end{abstract}




\section{Kidney Blood Pressure Research}

Tong/Luo/Liu: Intervention in Mast Cells on RI/RI

\section{Introduction}

Renal ischemia/reperfusion injury (RI/RI) is a common clinical problem that is increasing in prevalence and is associated with higher morbidity andmortality, as well as prolonged length of hospitalization [1]. RI/RI is often associated with an increase in plasma levels of blood urea nitrogen(BUN), serum creatinine(Scr), and numerous inflammatory factors and focal destruction of tubular epithelial cells [2]. Despite extensive studies on RI/ $\mathrm{RI}$, the mechanisms behind RI/RI and an effective way to decrease renal injury remain to be elucidated.

Mast cells are ordinarily distributed in normal connective tissue, mainly located adjacent to blood and lymphatic vessels, nerves, and epithelial surfaces, as well as in the skin and in the gastrointestinal and respiratory systems [3]. Under normal circumstances, mast cells are very sparsely distributed in the kidneys, but the number of mast cells increases dramatically during RI/RI [4]. When mast cells are stimulated, numerous mediators, such as histamine, trypsin-like enzyme, chymase, heparin, and a host of cytokines are released from mast cells, and under pathological conditions, they produce a wide array of biological effects [5]. Histamine is an amine substance released by mast cell degranulation, and histamine receptors are significantly involved in allergic reactions, inflammatory responses, and modulation of the body's immune function, as well aspromotion of the secretion of gastric acid and the maintenance of endothelial function [5]. It has been reported that the histamine antagonist ketotifen could improve the survival rate of rats subjected to intestinal ischemia reperfusion injury [6]. Other reports demonstrated that inhibition of inflammatory factors such as TNF- $\alpha$, IL-6, and ICAM-1, as well as inhibition of lipid peroxidation can all protect kidneys against renal ischemia reperfusion-induced injury [7-9].

In this study, renal injury in rats was induced by bilateral renal artery and vein occlusion followed by reperfusion. Cromolyn sodium (a mast cell membrane stabilizer), ketotifen (a histamine receptor $\mathrm{H} 1$ antagonist), and compound 48/80 (a mast cell degranulation agent) were intravenously administered 5 min before reperfusion through the tail vein. The effects of pharmacological intervention in mast cell function before reperfusion on attenuating renal ischemia-reperfusion injury was investigated.

\section{Materials and Methods}

\section{Animals and reagents}

Sprague-Dawley (SD) rats (180-220 g)were supplied by the Animal Research Center of Shantou University Medical College, Shantou, China. All of the procedures and care administered to theanimals were been approved by the Institutional Ethics Committee. Cromolyn sodium, ketotifen, compound 48/80, and other reagents were purchased from Sigma.

\section{Animal experimental design}

Fifty SD rats were randomly assigned to five groups (10 rats per group): (1) sham group; (2) I/R group: $\mathrm{I} / \mathrm{R}$ was induced by bilateral renal arteryand vein occlusion for $45 \mathrm{~min}$ followed by $24 \mathrm{~h}$ of reperfusion; (3) cromolyn sodium treatment group (CS+I/R): $45 \mathrm{~min}$ of ischemia followed by $24 \mathrm{~h}$ reperfusion with cromolyn sodium pretreatment ( $25 \mathrm{mg} / \mathrm{kg}$, i.v.) 5 min prior to reperfusion; (4) ketotifen treatment group (K+I/R): $45 \mathrm{~min}$ of ischemia followed by $24 \mathrm{~h}$ reperfusion with ketotifen pretreatment (1 mg/kg, i.v.) $5 \mathrm{~min}$ prior to reperfusion; (5) compound 48/80 treatment group (C+I/R): $45 \mathrm{~min}$ of ischemia followed by $24 \mathrm{~h}$ reperfusion with compound $48 / 80$ pretreatment $(0.75 \mathrm{mg} / \mathrm{kg}$, i.v.) $5 \mathrm{~min}$ prior to reperfusion.

Surgical procedures of RI/RI

SD rats were anesthetized with $1 \%$ pentobarbital sodium $(50 \mathrm{mg} / \mathrm{kg})$ via peritoneal injection. The abdominal cavity was opened, and the renal artery and vein were separated bilaterally. Each artery and vein was occluded for $45 \mathrm{~min}$ by two artery clamps, and success was confirmed by observing color change in the 


\section{Kidney Blood Pressure Research}

renal tissue. The artery clamps were removed $45 \mathrm{~min}$ later,and the renal arteries and veins were allowed to reperfuse for $24 \mathrm{~h}$. Blood samples were collected from the inferior venacava and centrifuged at 3600 rpm for $15 \mathrm{~min}$ to harvest the sera. The left kidneys of animals were removed and immediately excised for histopathologic evaluation and injury scores or stored at $-20^{\circ} \mathrm{C}$ for the analyses described below.

\section{Histopathologic evaluation}

Four-micron-thick sections of kidneys were cut and stained with hematoxylin and eosin (H\&E). Samples were blindly analyzed todetermine the extent of kidney injury based on the technique outlined by Erdogan et al. [10]. Briefly, 24 areas corresponding to the kidney proximal tubules were graded for the degree of renal damage based on each of the following parameters:tubular cell necrosis, cytoplasmic vacuole formation, hemorrhage, and tubular dilatation. Specifically, one whole deep coronal section was examined under the microscope and graded according to the extent of damage, based on the percentage of involvement of the kidney. Higher scores represent more severe damage, with the maximum score being 4 [0, histopathological changes <10\%; 1, (10\%-25\%); 2, (25\%-50\%); 3, (50\%-75\%); and 4, (75\%-100\%)]. The mean score for each parameter was determined and subjected to statistical analysis [11, 12].

\section{Assessment of renal function}

Blood samples were obtained from the inferior venacava $24 \mathrm{~h}$ after reperfusion. BUN and Scr levelswere assayed by the $o$-phthalaldehyde and picric acid methods for the assessment of renal function [7].

Measurement of superoxide dismutase (SOD) activity and malondialdehyde (MDA) content

The SOD activity and MDA content in renal tissues were measured to assess lipid peroxidation as described previously [7]. Kidney specimens were collected after reperfusion for $24 \mathrm{~h}$ and the blood wasrinsed off thoroughly. Each kidney was homogenized in ice-cold normal salineand then centrifuged at $3600 \mathrm{rpm}$ for $10 \mathrm{~min}$ to harvest the supernatant. The content of total protein in the supernatant was measured by Coomassie brilliant blue method as described by the manufacturer's protocol. The SOD activity and MDA content were measured by the xanthine oxidase and thiobarbituric acid methods. The level of lipid peroxides was expressed as $\mathrm{U}$ of SOD/mg protein and nmol of MDA/mg protein.

Measurement of tumor necrosis factor $\alpha(T N F-\alpha)$ content

The quantity of TNF- $\alpha$ in renal tissues was measured to assess inflammatory injury as described previously [13]. The TNF- $\alpha$ content was measured using the double-antibody sandwich ELISA method. The absorbance was measured at $495 \mathrm{~nm}$. The content of inflammatory injury was expressed as ng of TNF- $\alpha / \mathrm{g}$ protein.

\section{Measurement of interleukin-6 (IL-6) content}

The quantityof IL-6 in renal tissues was measured to assess inflammatory injury as described previously $[14,15]$. The sampling process was the same as above and the IL-6 content was measured using the double-antibody sandwich ELISA method. The absorbance was measured at $450 \mathrm{~nm}$. The content of inflammatory injury was expressed as pg of IL-6/mg protein.

\section{Determination of histamine in serum}

At the pre-determined time, a $0.3-\mathrm{mL}$ blood sample was obtainedfrom the inferior venacava $24 \mathrm{~h}$ after reperfusion. Histamine content in plasma was determined by theuse of a histamine assay kit as described previously [4].

\section{Western blot analysis}

Western blot analysis was conducted as described previously [16]. Briefly, renal tissues were homogenized in protein lysate buffer. The homogenates were resolved on polyacrylamide SDS gels, and electrophoretically transferred to polyvinylidene difluoride membranes. The membranes were blocked with $3 \%$ BSA, incubated with primary antibodies against active intracellular adhesion molecule-1 (ICAM-1) and then with alkaline phosphatase-conjugated secondary antibody. The membranes were subsequently 


\section{Kidney Blood Pressure Research}

Fig. 1. Histopathologic evaluation of kidney injury. Light microscope images $(\times 400) a$, $b, c, d$, and $e$ correspond to sham group, I/R group, $\mathrm{CS}+\mathrm{I} / \mathrm{R}$ group, $\mathrm{K}+\mathrm{I} / \mathrm{R}$ group, and $\mathrm{C}+\mathrm{I} / \mathrm{R}$ group, respectively. Quantitative injury scores, expressed as the mean $\pm \mathrm{SD}$, are shown in Fig. 1f. A significant increase relative to the sham group is denoted by "*” $(p<0.01)$, a significant decrease relative to the I/R group is denoted

by “\#” ( $p<0.05)$, and a significant increase relative to the I/R group is denoted by “\#\#” $(p<0.01)$.

developed by 5-bromo-4-chloro-3-indolyl phosphate/nitro blue tetrazolium. Blots were stained with anti$\beta$-actin antibodies, and protein levels were normalized with respect to $\beta$-actinband density.

\section{Statistical analysis}

All data were expressed as the mean value \pm standard deviation (SD). Statistical analysis between groups was carried out using ANOVA with post-hoc testing and Pearson correlation analysis. A value of less than $0.01(P<0.01)$ was used for statistical significance.

\section{Results}

\section{Histopathologic evaluation}

Light microscopy images of kidney sections are shown in Fig. 1. Tubular cell necrosis, cytoplasmic vacuoles, hemorrhage, and tubular dilatation were observed in histological specimens from the I/R group (Fig. 1b) but were absent in the sham group (Fig. 1a). Histological alterations were markedly reduced in specimens from the cromolyn sodium-and ketotifen-treated groups (Fig. 1c and 1d) compared to the I/R group. Histological alterations were increased in specimens from the compound 48/80-treated group (Fig. 1e) compared with the I/R group. The corresponding quantitative analysis is shown in Fig. 1f.

\section{Serum level of BUN and Scr}

As shown in Fig. 2, the serum levels of BUN and Scr in RI/RI rats were significantly higher than those in sham rats. The level of BUN was $6.45 \pm 0.48 \mathrm{mmol} / \mathrm{L}$ in sham rats, whereas the level of BUN reached $24.13 \pm 0.98 \mathrm{mmol} / \mathrm{L}$ in the I/R rats. Administration of cromolyn sodium and ketotifen significantly reduced the levels of BUN $(16.78 \pm 1.08 \mathrm{mmol} / \mathrm{L}$ for the CS+I/R group and $16.03 \pm 0.85 \mathrm{mmol} / \mathrm{L}$ for the $\mathrm{K}+\mathrm{I} / \mathrm{R}$ group), whereas administration of compound 


\section{Kidney \\ Blood Pressure \\ Research}

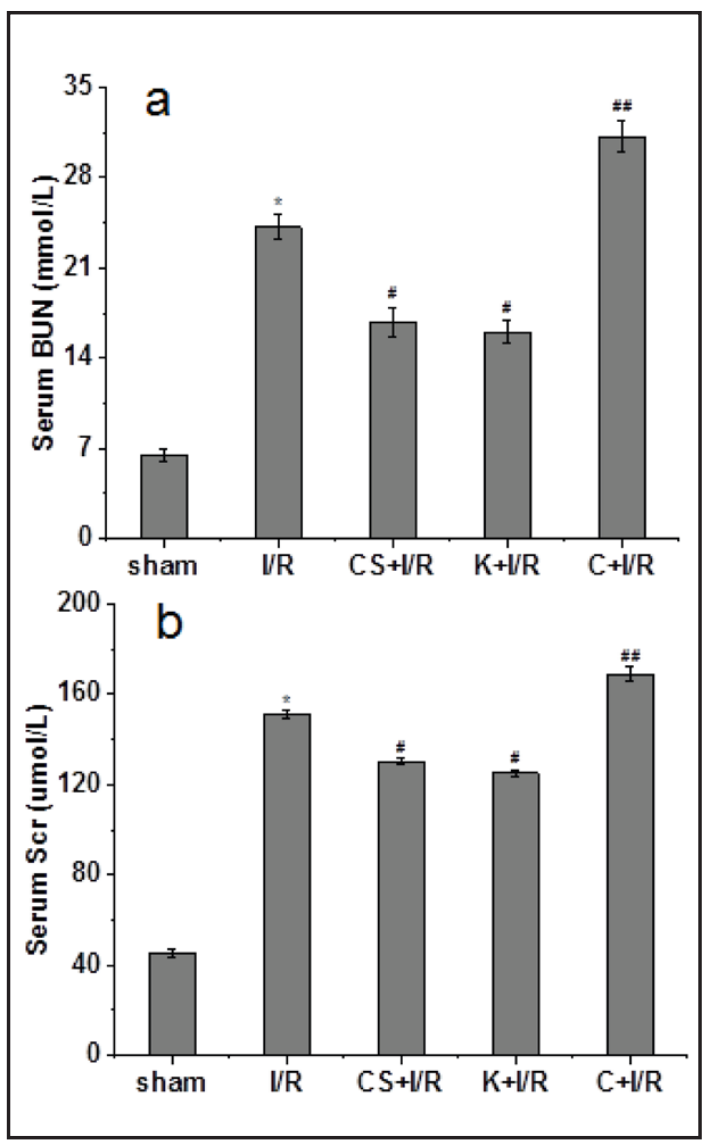

Fig. 2. Serum level of BUN and Scr. The resultsare expressed as the mean $\pm \mathrm{SD}$. A significant increase relative to the sham group is denoted by “*” $(p<0.01)$, a significant decrease relative to the I/R group is denoted by "\#" $(p<0.05)$, and a significant increase relative to the I/R group is denoted by "\#\#” ( $p<0.01)$.

$48 / 80$ significantly increased the level of BUN $(31.21 \pm 1.21 \mathrm{mmol} / \mathrm{L})$ compared with that of I/R rats. The level of Scr was $45.13 \pm$ $1.85 \mu \mathrm{mol} / \mathrm{L}$ in sham rats, whereas the level of Scr reached $151.27 \pm 2.11 \mu \mathrm{mol} / \mathrm{L}$ in $\mathrm{I} / \mathrm{R}$

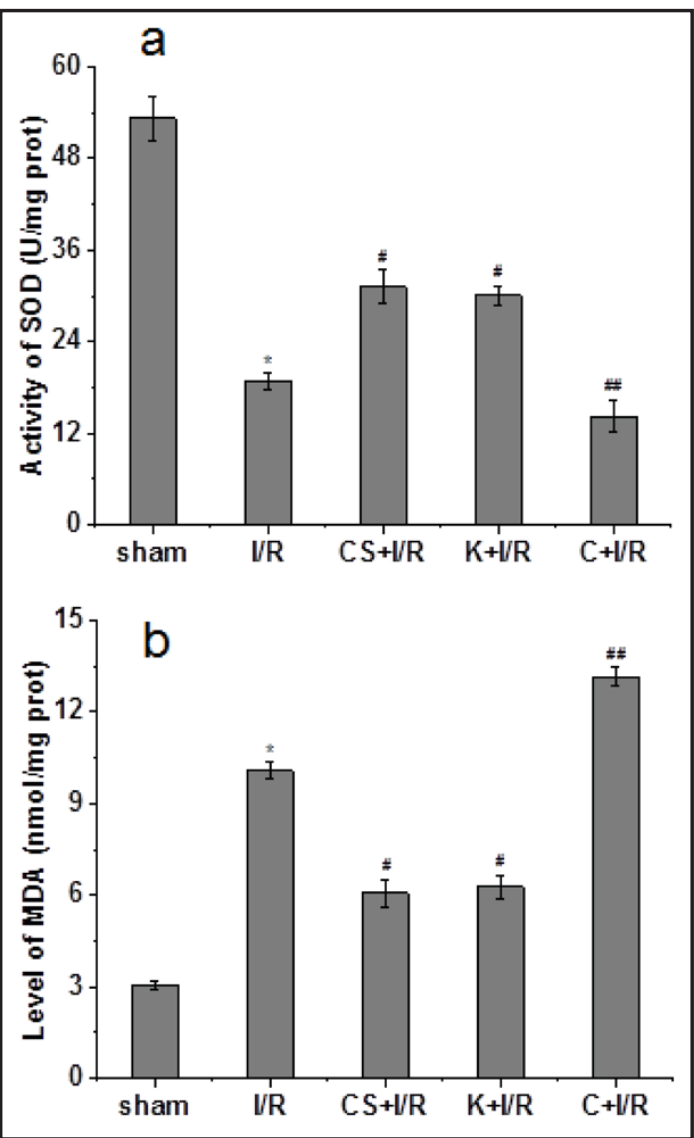

Fig. 3. The activity of SOD and the level of MDA in renal tissues. The results are expressed as the mean \pm SD. (a) A significant decrease relative to the sham group is denoted by "*” $(p<0.01)$, a significant increase relative to the I/R group is denoted by "\#" $(p<0.05)$, and a significant decrease relative to the I/R group is denoted by "\#\#" ( $p<0.01)$. (b) A significant increase relative to the sham group is denoted by “*” $(p<0.01)$, a significant decrease relative to the I/R group is denoted by "\#” ( $p<0.05)$, and a significant increase relative to the I/R group is denoted by "\#\#" ( $p<0.01)$.

rats. Administration of cromolyn sodium and ketotifen significantly reduced the levels of Scr $(130.16 \pm 1.28 \mu \mathrm{mol} / \mathrm{L}$ for the $\mathrm{CS}+\mathrm{I} / \mathrm{R}$ group and $125.06 \pm 1.65 \mu \mathrm{mol} / \mathrm{L}$ for the $\mathrm{K}+\mathrm{I} / \mathrm{R}$ group), whereas administration of compound 48/80 increased the levels of Scr (168.88 \pm $3.09 \mu \mathrm{mol} / \mathrm{L}$ ) compared with I/R rats.

The activity of SOD and the level of MDA in renal tissues

The activities of SOD and the levels of MDA in renal tissues are shown in Fig. 3. The activity of SOD in renal tissues induced by I/R (18.78 $\pm 1.19 \mathrm{U} / \mathrm{mg}$ protein) was significantly less than that in the sham group (53.25 $\pm 2.87 \mathrm{U} / \mathrm{mg}$ protein). Administration of cromolyn sodium and ketotifen significantly increased the activity of SOD $(31.19 \pm 2.13 \mathrm{U} / \mathrm{mg}$ protein for the $\mathrm{CS}+\mathrm{I} / \mathrm{R}$ group and $30.08 \pm 1.24 \mathrm{U} / \mathrm{mg}$ protein for the $\mathrm{K}+\mathrm{I} / \mathrm{R}$ group) in renal tissues compared with that in the I/R group. Administration of compound 48/80 decreased the activity of SOD 


\section{Kidney \\ Blood Pressure Research}

$(14.17 \pm 2.05 \mathrm{U} / \mathrm{mg}$ protein) compared with that in the I/R group. The level of MDA in renal tissues in the I/R group (10.08 $\pm 0.27 \mathrm{nmol} / \mathrm{mg}$ protein) was significantly higher than that in the sham group (3.05 $\pm 0.16 \mathrm{nmol} / \mathrm{mg}$ protein). Administration of cromolyn sodium and ketotifen significantly reduced the level of MDA $6.05 \pm 0.43 \mathrm{nmol} / \mathrm{mg}$ protein for the $\mathrm{CS}+\mathrm{I} / \mathrm{R}$ group and $6.27 \pm 0.38$ $\mathrm{nmol} / \mathrm{mg}$ protein for the $\mathrm{K}+\mathrm{I} / \mathrm{R}$ group) in renal tissues, compared with the level of MDA in I/R group. Administration of compound 48/80 increases the level of MDA (13.15 $\pm 0.32 \mathrm{nmol} / \mathrm{mg}$ protein), compared with that in the I/R group.

The level of TNF- $\alpha$ and IL-6 in renal tissues

The levels of TNF- $\alpha$ in renal tissues are shown in Fig. 4a. The level of TNF- $\alpha$ induced by I/R $(1.132 \pm 0.0125 \mathrm{ng} / \mathrm{g}$ protein) was significantly higher than that in the sham group $(0.3617 \pm$ $0.0118 \mathrm{ng} / \mathrm{g}$ protein). Administration of cromolyn sodium and ketotifen significantly reduced the level of TNF- $\alpha$ $(0.6117 \pm 0.0132 \mathrm{ng} / \mathrm{g}$ protein for the $\mathrm{CS}+\mathrm{I} / \mathrm{R}$ group and $0.6198 \pm 0.0132$ $\mathrm{ng} / \mathrm{g}$ protein for the $\mathrm{K}+\mathrm{I} / \mathrm{R}$ group) in renal tissues, compared with the level of TNF- $\alpha$ in the I/R group. Administration of compound 48/80 increased the level of TNF- $\alpha(1.347 \pm 0.0128 \mathrm{ng} / \mathrm{g}$ protein), compared with that in theI/R group. The levels of IL- 6 in renal tissues are

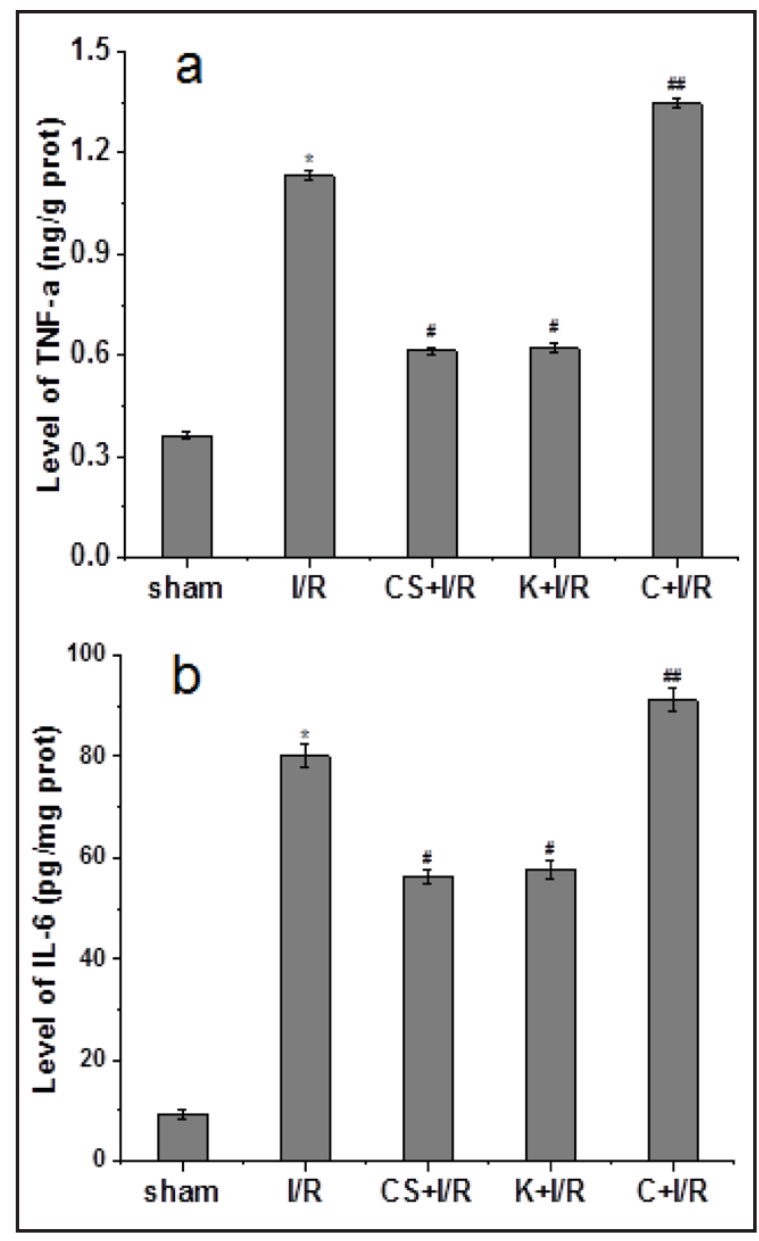

Fig. 4. The level of TNF- $\alpha$ and IL- 6 in renal tissues. The results are expressed as the mean \pm SD. A significant increase relative to the sham group is denoted by "*” $(p<0.01)$, a significant decrease relative to the I/R group is denoted by “\#” ( $p<0.05)$, and a significant increase relative to the I/R group is denoted by "\#\#" ( $p<0.01)$. demonstrated in Fig. 4b. The level of IL-6 induced by I/R $(80.13 \pm 2.31 \mathrm{pg} / \mathrm{mg}$

protein) was significantly higher than that in the sham group $(9.18 \pm 1.05 \mathrm{pg} / \mathrm{mg}$ protein). Administration of cromolyn sodium and ketotifen significantly reduced the level of IL-6 $(56.18 \pm 1.29 \mathrm{pg} / \mathrm{mg}$ protein for the $\mathrm{CS}+\mathrm{I} / \mathrm{R}$ group and $57.72 \pm 1.83 \mathrm{pg} / \mathrm{mg}$ proteinfor the $\mathrm{K}+\mathrm{I} / \mathrm{R}$ group) in renal tissues compared with the level of IL- 6 in the I/R group. Administration of compound 48/80 increased the level of IL-6 (91.23 $\pm 2.19 \mathrm{pg} / \mathrm{mg}$ protein) compared with that in the I/R group.

\section{Changes in serum histamine levels}

The levels of serum histamine for different groups are shown in Fig. 5. The level of histamine induced by I/R $(167.24 \pm 2.16 \mathrm{nM})$ was significantly higher than that in the sham group (46.13 $\pm 1.04 \mathrm{nM}$ ). Administration of cromolyn sodium and ketotifen reduced the level of histamine $(146.15 \pm 2.27 \mathrm{nM}$ for the $\mathrm{CS}+\mathrm{I} / \mathrm{R}$ group and $145.83 \pm 1.98 \mathrm{nM}$ for the $\mathrm{K}+\mathrm{I} / \mathrm{R}$ group) in serum compared with the level of histamine in the I/R group. Administration of compound 48/80 significantly increased the level of histamine (196.37 $\pm 2.45 \mathrm{nM}$ ) compared with that in the I/R group. 


\section{Kidney Blood Pressure Research}

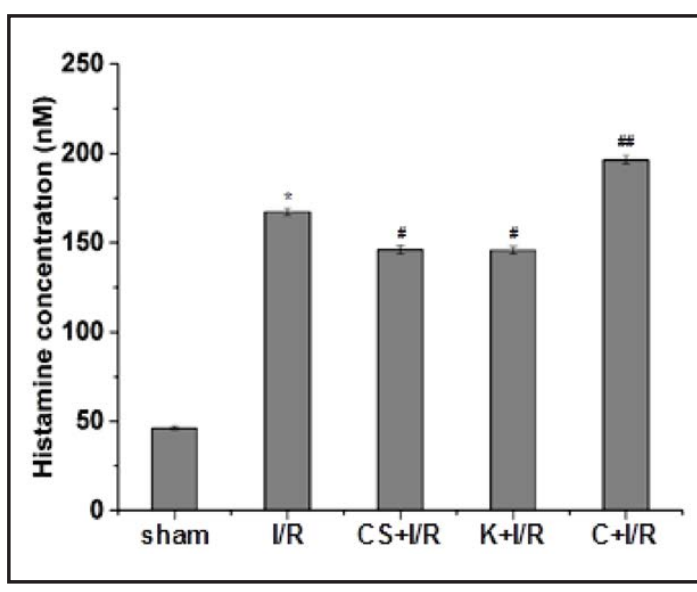

Fig. 5. The concentration of histamine in plasma. The results are expressed as the mean \pm SD. A significant increase relative to the sham group is denoted by “*” ( $p<0.01)$, a significant decrease relative to the I/R group is denoted by "\#” ( $p<0.05)$, and a significant increase relative to the I/R group is denoted by “\#\#” ( $p<0.01)$.

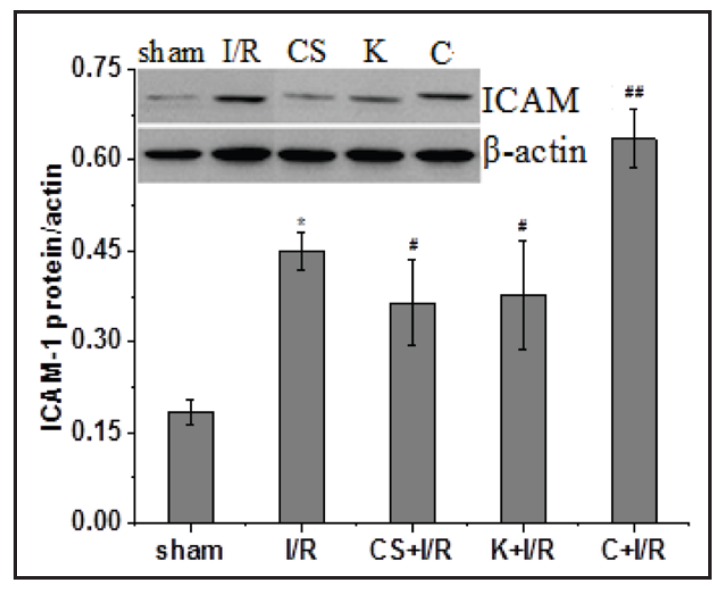

Fig. 6. The expression of ICAM-1 in renal tissues. The results are expressed as the mean \pm SD. A significant increase relative to the sham group is denoted by “*” ( $p<0.01)$, a significant decrease relative to the I/R group is denoted by "\#” ( $p<0.05)$, and a significant increase relative to the $\mathrm{I} / \mathrm{R}$ group is denoted by "\#\#" ( $p<0.01)$.

The expression of ICAM-1 in renal tissues

The expression of ICAM-1 in renal tissues is shown in Fig. 6. It can be seen that the expression of ICAM-1 induced by I/R was significantly higher than in the sham group. Administration of cromolyn sodium and ketotifen significantly downregulated the expression of ICAM-1 in renal tissues compared with the expression of ICAM-1 in the I/R group. Administration of compound 48/80 significantly upregulated the expression of ICAM1compared with that in theI/R group.

\section{Correlation analysis}

Correlation analysis amongst histamine, BUN, Scr, SOD, MDA, TNF- $\alpha$, IL- 6 contentand ICAM-1 expression was conducted. The results showed that the serum histamine level had a positive correlation with serum BUN $(r=0.817, p<0.01)$ and Scr levels $(r=0.831, p<0.01)$ and that serum BUN and Scr levels had a negative correlation with SOD activity $(r=-0.654$, $p<0.01)$ but a positive correlation with MDA levels $(r=0.732, p<0.01)$, TNF- $\alpha$ levels $(r=$ $0.802, p<0.01)$, IL-6 levels ( $r=0.884, p<0.01)$ and ICAM-1 expression $(r=0.706, p<0.01)$.

\section{Discussion}

Altering mast cell activity and function has proven to be a promising technique to reduce intestine, lung, heart, and brain ischemia reperfusion injury [6,17-20]. It has been reported that cromolyn sodium (a mast cell stabilizer) can interfere with mast cell function to reduce lung damage during the early secondary lung injury phase of acute pancreatitis and that mast cells could alleviate organ damage by increasing the expression of neutrophils, monocytes, and ICAM-1 [21]. Previous studies demonstrated that cromolyn sodium, working as a mast cell stabilizer, and ketotifen, working as a histamine receptor $\mathrm{H}_{1}$ antagonist, decreased intestinal ischemia reperfusion injury, while compound 48/80, which works as a mast cell degranulation agent, aggravated intestinal ischemia reperfusion injury [22]. In the present study, renal ischemia reperfusion led to renal damage and was accompanied by elevated 


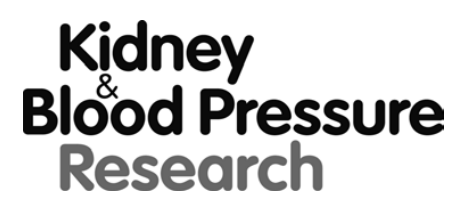

Kidney Blood Press Res 2016;41:335-344

\begin{tabular}{|l|l|}
\hline DOI: 10.1159/000443437 & (c) 2016 The Author(s). Published by S. Karger AG, Basel \\
\hline
\end{tabular}

serum BUN and Scr; administration of cromolyn sodium and ketotifen attenuated I/Rinjury, whereas compound 48/80 exacerbated I/R injury.

Histamine, one of the main active substances produced by mast cells, can increase vascular permeability, induce inflammatory cell infiltration, stimulate epithelial cells, and release cytokines, all of which cause or exacerbate tissue damage that can further induce mast cell activation. Histamine antagonists are widely used in protection from ischemia reperfusion injury, and some studies show that ketones can decrease intestinal ischemia reperfusion injury, while compound 48/80 can increase damage [5, 6]. Our results showed that I/R increased serum histamine, while cromolyn sodium and ketotifen reduced serum histamine and compound 48/80 exhibited the opposite effect. At the same time, correlation analysis results demonstrated that serum histamine concentrations had a positive correlation with serum BUN and Scr levels. The above results suggest that endogenous mast cells are activated after renal ischemia reperfusion and subsequently release a large number of active substances such as histamine that damage kidney tissues.

Renal I/R has been demonstrated to involve the production of reactive oxygen species (ROS) and dependent signaling cascades [23-26]. It has been reported that mast cells can increase oxidative damage and promote the production of ROS, which reduce the activity of SOD and increase MDA levels [27]. The present study demonstrated thatcromolyn sodium and ketotifen both improved SOD activity and decreased MDA content with reduced renal oxidative injury, while compound 48/80 displayed the opposite effect, leading to increased I/R damage. Correlation analysis results showed that serum BUN and Scr had a negative correlation with SOD activity but a positive correlation with MDA content. The above results suggest that mast cells may participate in I/R renal injury through mediating oxidative stress.

I/R injury involves the inflammatory response of both the innate and adaptive immune systems through exaggerated inflammatory cell infiltration and tubular epithelial cell activation [28-30]. When renal I/R injury occurs, inflammatory cells initially infiltrate into the damaged renal tissue and promote marked pro-inflammatory mediator secretion; the latter promotes the infiltration of inflammatory cells into the damaged tissues and further promotes inflammatory tissue responses [31,32], which results in a vicious positive feed back loop. Furthermore, infiltrated inflammatory cells reduce renal blood flow, which leads to microcirculatory dysfunction $[33,34]$. Our results showed that I/R injury induced the production of TNF- $\alpha$, IL-6, and ICAM-1. Tissue histology showed significant pathology, with renal tissue bleeding, edema, and inflammatory cell infiltration. Serum BUN, Scr were also significantly increased. Administration of cromolyn sodium and ketotifen reduced the level of TNF- $\alpha$, IL-6 and downregulated the expression of ICAM-1, while compound 48/80 had the opposite effect. These results imply that inhibition of mast cell degranulation and antagonistic histamine effects both can reduce I/R injury whereas promotion of mast cell degranulation can aggravate I/R injury. Correlation analysis results showed that serum BUN and Scr had a positive correlation with TNF- $\alpha$, IL- 6 and ICAM- 1 . These results showed that the activation of mast cells is involved in the production of proinflammatory factors, which also contributed to renal I/R injury.

\section{Conclusion}

In summary, our results indicate that pharmacological modulation of mast cell activity significantly altered renal ischemia-reperfusion injury. The inhibition of mast cell function before reperfusion and the reduction of histamine release alleviated oxidative damage and the inflammatory response, protecting the kidney from I/R injury. 


\title{
Kidney \\ Blood Pressure Research
}

\section{Disclosure Statement}

\author{
Nothing to declare.
}

\section{Acknowledgements}

This work was financially supported by the Department of Education, Guangdong Government, under the Top-tier University Development Scheme for Research and Control of Infectious Diseases.

\section{References}

1 Seifi B, Kadkhodaee M, Bakhshi E, Ranjbaran M, Zahmatkesh M, Sedaghat Z, Ahghari P, Esmaeili P: Angiotensin II in paraventricular nucleus contributes to sympathoexcitation in renalischemia-reperfusion injury by AT1 receptor and oxidative stress. J Surg Res 2015;193:361-367.

2 Ling H, Chen H, Wei M, Meng X, Yu Y, Xie K: The effect of autophagy on inflammation cytokines in renal ischemia/reperfusion injury. Inflammation 2016;39:347-356.

3 Armbrust T, Batusic D, Ringe B, Ramadori G: Mast cells distribution in human liver disease and experimental rat liver fibrosis. Indications for mast cell participation in development of liver fibrosis. J Hepatol 1997;26:1042-1054.

4 Kaneko H, Koshi S, Hiraoka T, Miyauchi Y, Kitamura N, Inoue M: Inhibition of post-ischemic reperfusion injury of the kidney by diamine oxidase. Biochim Biophys Acta 1998;1407:193-199.

5 HuangP, Li X, Luo C, Zhang A, Liu J: Effect of intervention for mast cell function before reperfusion on intestinalischemia-reperfusion-induced early liver injury in rats. Chin J Pathophysiol 2014;30:85-90.

6 Kalia N, Brown NJ, Wood RF, Pockley AG: Ketotifen abrogates local and systemic consequences of rat intestinal ischemia-reperfusion injury. J Gastroenterol Hepatol 2005;20:1032-1038.

7 Li Z, Wang Y: Effect of NADPH oxidase inhibitor-apocynin on the expression of Src homology-2 domaincontaining phosphatase-1 (SHP-1) exposed renal ischemia/reperfusion injury in rats. Toxicol Rep 2015;2:1111-1116.

8 Li M, Luo Z, Chen X, Xuan J, Ye F, Liu H, Chen K: Use of contrast enhanced ultrasound to monitor rabbit renal ischemia/reperfusion injury and correlations between time-intensity curve parameters and renal ICAM-1 expression. Clin Hemorheol Microcirc 2015;59:123-131.

9 Sharyo S, Kumagai K, Yokota-Ikeda N, Ito K, Ikeda M: Amelioration of renal ischemia-reperfusion injury by inhibition of IL-6 production in the poloxamer 407-induced mouse model of hyperlipidemia. J Pharmacol Sci 2009;110:47-54.

10 Erdogan H, Fadillioglu E, Yagmurca M, Ucar M, Irmak MK: Protein oxidation and lipid peroxidation after renal ischemia-reperfusion injury: protective effects of erdosteine and $\mathrm{N}$-acetylcysteine. Urol Res 2006;34:41-46.

11 He X, Xu X, Fan M, Chen X, Sun X, Luo G, Chen L, Mu Q, Feng Y, Mao Q, Chao Z: Preconditioning with hyperbaric oxygen induces tolerance against renal ischemia-reperfusion injury via increased expression of heme oxygenase-1. J Surg Res 2011;170:271-277.

12 Yang FJ, He YH, Zhou JH: Fenofibrate pre-treatment suppressed inflammation by activating phosphoinositide 3 kinase/protein kinase B (PI3K/Akt) signaling in renal ischemia-reperfusion injury. J Huazhong U Sci Med 2015;35:58-63.

13 Akbulut G, Dilek ON, Kahraman A, Köken T, Serteser M:The correlation between renal tissue oxidative stress parameters and TNF-alpha levels in an experimental model of ischemia-reperfusion injury in mice. Ulus Travma Acil Cer 2005;11:11-16.

14 Patel NS, Chatterjee PK, Di Paola R, Mazzon E, Britti D, De SarroA,Cuzzocrea S, Thiemermann C: Endogenous interleukin- 6 enhances the renal injury, dysfunction, and inflammation caused by ischemia/ reperfusion. J Pharmacol Exp Ther 2005;312:1170-1178. 


\section{Kidney \\ Bloód Pressure Research}

\begin{tabular}{|c|c|}
\hline $\begin{array}{l}\text { DOI: } 10.1159 / 000443437 \\
\text { Published online: June } 16,2016\end{array}$ & $\begin{array}{l}\text { (c) } 2016 \text { The Author(s). Published by S. Karger AG, Basel } \\
\text { www.karger.com/kbr }\end{array}$ \\
\hline
\end{tabular}

Tong/Luo/Liu: Intervention in Mast Cells on RI/RI

15 Kielar ML, John R, Bennett M, Richardson JA, Shelton JM, Chen L, Jeyarajah DR, Zhou XJ, Zhou H, Chiquett B, Nagami GT, Lu CY: Maladaptive role of IL-6 in ischemic acute renal failure. J Am Soc Nephrol 2005;16:33153325.

16 Xiong T, Dong W, Fu H, Li Q, Deng C, Lei X, Guo L: Involvement of the nuclear factor- $\kappa$ B pathway in the adhesion of neutrophils to renal tubular cells after injury induced by neonatal postasphyxialserum. Mol Cell Biochem 2014;388:85-94.

17 Vural KM, Liao H, Oz MC, Pinsky DJ: Effects of mast cell membrane stabilizing agents in a rat lung ischemiareperfusion model. Ann Thorac Surg 2000;69:228-232.

18 Frangogiannis NG, Youker KA, Rossen RD, Gwechenberger M, Lindsey MH, Mendoza LH, Michael LH, Ballantyne CM, Smith CW, Entman ML: Cytokines and the microcirculation in ischemia and reperfusion. J Mol Cell Cardiol 1998;30:2567-2576.

19 Lindsberg PJ, Strbian D, Karjalainen-LindsbergML: Mast cells as early responders in the regulation of acute bloodbrain barrier changes after cerebral ischemia and hemorrhage. J Cereb Blood Flow Metab 2010;30:689-702.

20 Li X, Xie Z, Lin M, Huang R, Liang Z, Huang W, Jiang W:Renalaseprotects the cardiomyocytes of SpragueDawley rats against ischemia and reperfusion injury by reducing myocardial cell necrosis and apoptosis. Kidney Blood Press Res 2015;40:215-222

21 Dib M, Zhao X, Wang XD, Andersson R: Role of mast cells in the development of pancreatitis-induced multiple organ dysfunction. Br J Surg 2002;89:172-178.

22 Hei ZQ, Huang PJ, Gan XL, Pang HY, Wei J: Influence of cromolyn sodium and compound 48/80 administered prior to and after reperfusion on the third day's survival rate in a rat intestinal ischemia model. Chin Med J (Engl) 2008;121:1843-1847.

23 Gang GT, Hwang JH, Kim YH, Noh JR, Kim KS, Jeong JY, Choi DE, Lee KW, Jung JY, Shong M, Lee CH: Protection of NAD(P)H: quinone oxidoreductase 1 against renal ischemia/reperfusion injury in mice. Free Radical Bio Med 2014;67:139-149.

24 Zhang G, Zou X, Miao S, Chen J, Du T, Zhong L, Ju G, Liu G, Zhu Y: The anti-oxidative role of micro-vesicles derived from human Wharton-Jelly mesenchymal stromal cells through NOX2/gp91(phox) suppression in alleviating renal ischemia-reperfusion injury in rats. PLoS One 2014;9:e92129.

25 Sehitoglu I, Tumkaya L, Bedir R, Kalkan Y, Cure MC, Yucel AF, Zorba OU, Yuce S, Cure E: Zoledronic acid aggravates kidney damage during ischemia reperfusion injury in rat. J Environ Pathol Toxicol Oncol 2015;34:53-61.

26 Li Y, Zhong D, Lei L, Jia Y, Zhou H, Yang B: Propofol prevents renalischemia-reperfusion injury via inhibiting the oxidative stress pathways. Cell Physiol Biochem 2015;37:14-26.

27 Okayama Y: Oxidative stress in allergic and inflammatory skin diseases. Curr Drug Targets Inflamm Allergy 2005;4:517-519.

28 Land WG: The role of postischemic reperfusion injury and other nonantigen-dependent inflammatory pathways in transplantation. Transplantation 2005;79:505-514.

29 Serteser M, Koken T, Kahraman A, Yilmaz K, Akbulut G, Dilek ON: Changes in hepatic TNF-alpha levels, antioxidant status, and oxidation products after renal ischemia/reperfusion injury in mice. J Surg Res 2002;107:234-240.

30 Guan X, Qian Y, Shen Y, Zhang L, Du Y, Dai H, Qian J, Yan Y: Autophagyprotects renal tubular cells against ischemia/reperfusion injury in atime-dependent manner. Cell Physiol Biochem 2015;36:285-298.

31 Ysebaert DK, De Greef KE, Vercauteren SR, Ghielli M, Verpooten GA, Eyskens EJ, De Broe ME: Identification and kinetics of leukocytes after severe ischaemia/reperfusion renal injury. Nephrol Dial Transplant 2000;15:1562-1574.

32 Facio FJ, Sena AA, Araujo LP, Mendes GE, Castro I, Luz MA, Yu L, Oliani SM, Burdmann EA: Annexin 1 mimetic peptide protects against renal ischemia/reperfusion injury in rats. J Mol (Berl) 2011;89:51-63.

33 Bolisetty S, Agarwal A: Neutrophils in acute kidney injury: not neutral any more. Kidney Int 2009;75:674676.

34 Jing XX, Wang ZG, Ran HT, Li L, Wu X, Li XD, Peng XQ, Yang CJ, Li XS, Zhang QX: Evaluation of renal ischemia-reperfusion injury in rabbits using microbubbles targeted to activated neutrophils. Clin Imaging 2008;32:178-182. 